\section{Reducing the cost of inter- and intrastate conflict over water in the Jordan River basin}

\section{David J.H. Phillips}

A s shown in Figure 1, five riparians are present in the Jordan river basin (Lebanon, Syria, Israel, Jordan, and the West Bank - the latter representing part of the Occupied Palestinian Territories). ${ }^{1}$ The region constitutes a focal point of long-term conflict in the Middle East, and remains a key driver of global geopolitical instability. The availability of water resources is arguably an important element of the historical and ongoing conflict among the countries in the basin, the water-related concerns being driven especially by the arid nature of much of the region, and the past and present inequities in the distribution of fresh water. ${ }^{2}$ The only attempt to date to allocate fresh water in a basin-wide fashion involved the production of the Johnston Plan which was finalized at the end of September 1955, and was based on a consideration of irrigable areas only, ignoring groundwater resources. It has been argued that this approach does not match the present-day philosophy for determining the equitable and reasonable use of transboundary watercourses, and that the Johnston Plan proposals are therefore of limited utility at the current time. ${ }^{3}$

While considerable attention has been paid by previous authors to interstate conflicts over water resources in the Jordan river basin (and the region provides some of the best examples of significant conflicts being triggered at least in part by problems connected to water resource allocation and availability),${ }^{4}$ much less has been published concerning intrastate tensions of this nature. The present article addresses this, providing reflections on the connection between water allocations and conflicts in the countries of the basin as a whole, and comments on several economic aspects of relevance.

\section{The nature of conflict and cooperation}

Conflict and cooperation are not absolute; each varies along a continuum, as shown in Table 1. At a gross scale, it has been demonstrated that in most transboundary basins (including so-called "basins at risk"), cooperation tends to be more frequent than conflict - and armed hostilities triggered by water are in fact exceptionally rare (Figure 2). This has given rise to the notion that cooperation over shared water resources could be employed as the trigger for broader political cooperation between nations, although it has been emphasized that there is no universal relationship between these factors, and each transboundary basin varies in this regard. ${ }^{5}$

In relation to conflict and/or cooperation over water resources, the interactions between communities inhabiting distinct areas within a single state may reflect those

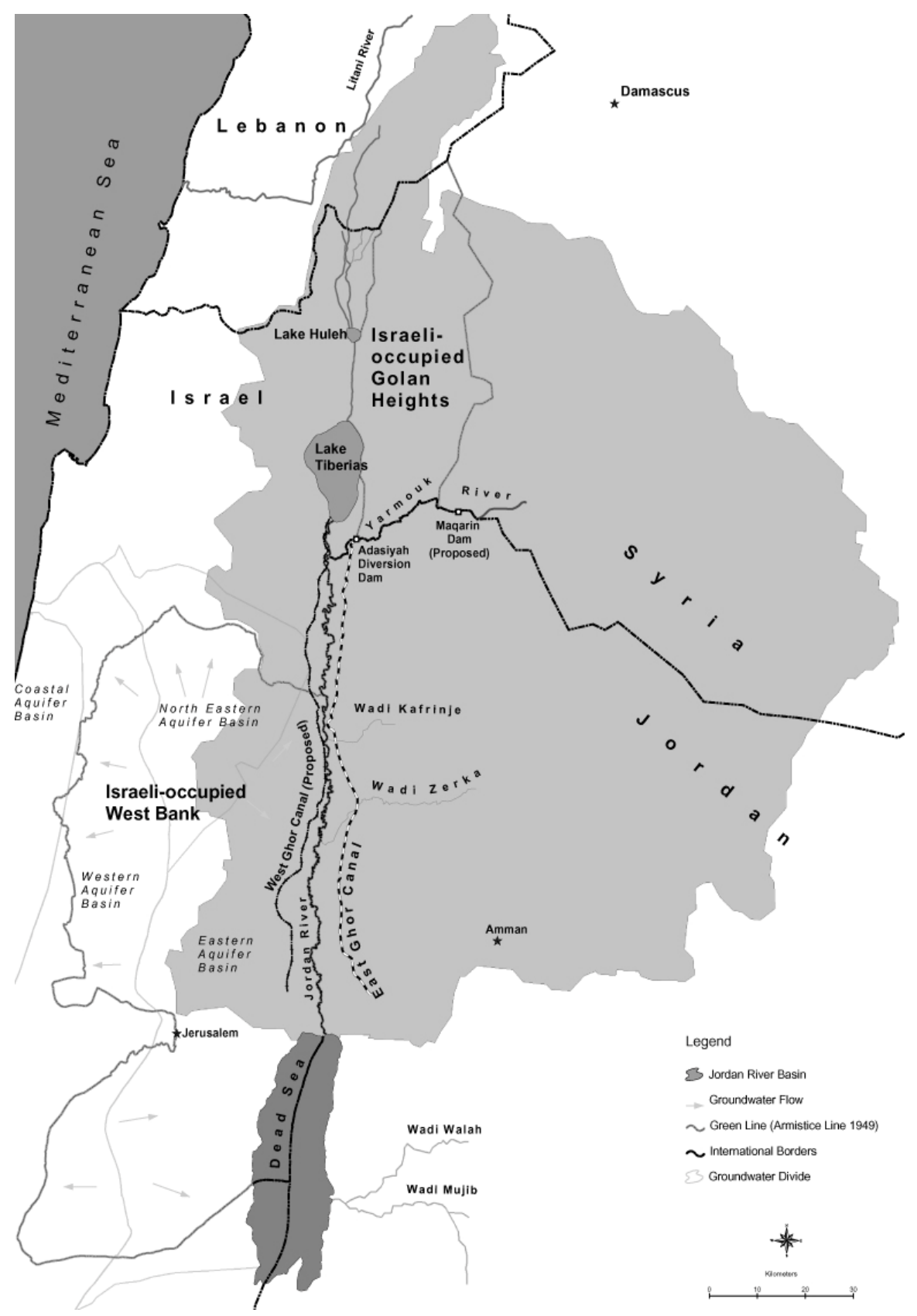

Figure 1: The Jordan river basin, and key watercourses. 
Table 1: The scale of intensity for conflict and cooperation

\section{Scale Example of event}

-7 Formal declaration of war.

-6 Extensive war-like acts causing deaths, dislocation or high strategic costs.

Small-scale military hostilities.

Political-military hostile actions.

Diplomatic-economic hostile actions.

Strong verbal expressions displaying hostility in interaction,

Mild verbal expressions displaying discord in interaction.

Neutral or non-significant acts for the inter-nation situation.

Minor official exchanges, talks or policy expressions; mild verbal

support.

Official verbal support of goals, values, or regime.

Officially sanctioned cultural or scientific support (non-strategic)

Non-military economic, technological or industrial agreements.

Military, economic or strategic support.

Major strategic alliances (e.g. an International Agreement).

Voluntary unification into one nation.

Source: Adapted from Yoffe and Larson (2001).

observed between entire countries. The following sections of the present article consider both interstate and intrastate relationships pertaining to water resources, among the five riparians of the Jordan river basin.

Interstate relationships and water resources

As has been widely documented, the riparians of the Jordan river basin have competed for the available regional water resources, and this has been ongoing effectively since the partition of Palestine (creating the state of Israel) in 1947 - or possibly even before this, when attempts were made to ensure that Israel's borders would extend to the Litani river in the north (in Lebanon). ${ }^{6}$ After partition, the efforts in the mid-1950s to generate a solution through the Johnston Plan sought to provide sufficient quantities of fresh water for all parties, emphasizing the plight of the refugees from the 1948 war. ${ }^{7}$ Since that time, conflicts over water have resurfaced on a number of occasions (e.g., frequent skirmishes in the mid-1960s connected to the construction of the National Water Carrier by Israel; the bombing by Israel of the East Ghor Canal in

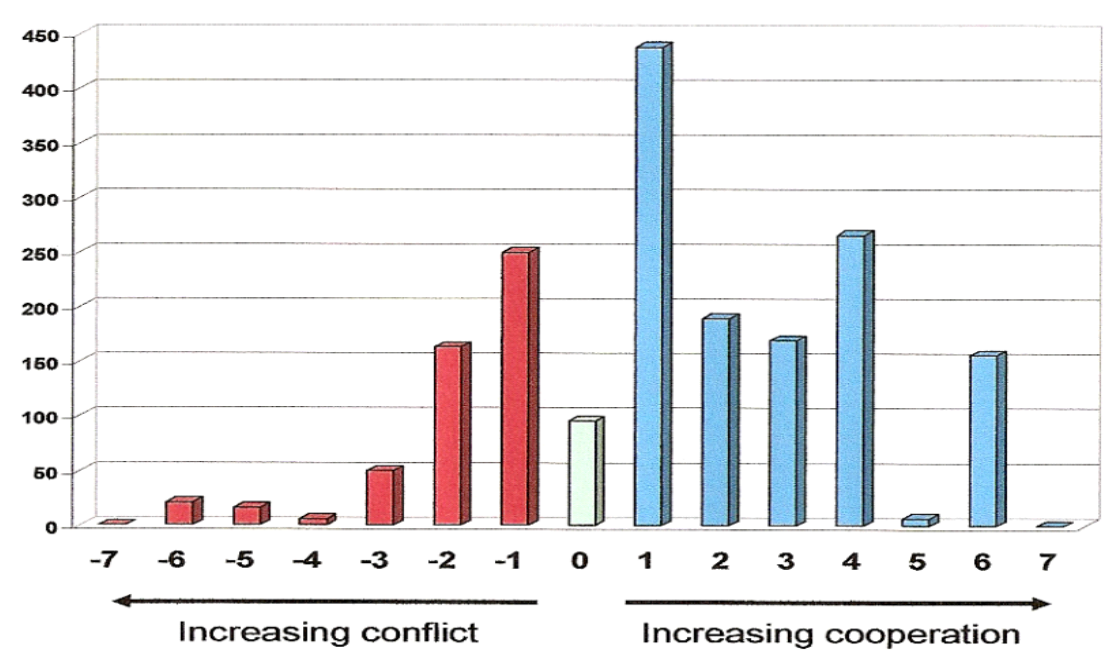

Figure 2: The numbers of recorded events among 1,831 events in total relating to conflict or cooperation over tran s-boundary water resources in basins at risk. Sources: Yoffe (2001); Giordano and Wolf (2003).

1969; military operations by Israel in the area of the Litani and Hasbani rivers in southern Lebanon in 1978 and 1982). Some parties contend that the 1967 "Six Day War" between Israel and its neighbors was triggered in part at least by concerns relating to the availability of water, ${ }^{8}$ and recent tensions between Israel and Lebanon concerning the abstraction of water by the latter party from the Wazzani Springs/Hasbani river reveal that the topic remains of importance in determining political relationships in the region. ${ }^{9}$ Indeed, some authors have continued to pursue arguments that the Litani river is hydrologically connected to the Jordan river basin, ${ }^{10}$ although these appear to be unfounded.

Interestingly (and providing proof that conflict and cooperation can exist in parallel), certain of the parties within the basin have cooperated significantly over water resources in recent years, e.g., in the signing of the Peace Treaty of 1994 between Israel and Jordan, containing a specific Annex on water; and in the attainment of an agreement for the construction of the Al-Wehdah (Unity) Dam, which remains ongoing on the Yarmouk river. While some parties have claimed that the continuation of the Joint Water Committee with Palestinian and Israeli representation during the period of the second Intifada (uprising) suggests a significant degree of cooperation over water between those parties also, Selby has rightly contested this, noting the ongoing subjugation and marginalization of the Palestinians in relation to their access to the regional water resource. ${ }^{11}$ 


\section{Intrastate conflicts over water}

Internal conflicts over water resources and their allocation have been observed at many of the levels shown in Table 1 in all the riparians to the Jordan river basin. While these are less frequently reported (and hence, are much less visible) than the interstate rivalries, they are probably more common, and are pervasive. Examples include the following five. First, tensions exist over the regional use of water in Lebanon, especially in connection to plans to expand the agricultural uses of water in southern Lebanon. ${ }^{12}$ The latter concerns respond to some degree to the fact that Lebanon has never been able to use the volumes of water from the Jordan river basin as proposed in the Johnston Plan (35 million cubic meters/year), and that the hydrological studies proposed in the Johnston Plan relating to the water resources in southern Lebanon were never completed. ${ }^{13}$ There remains scope for further consideration of the water resources available in southern Lebanon.

Second, competition occurs for water among various users in Syria. ${ }^{14}$ Syria is unusual among the riparians in the Jordan river basin, in that its per capita use of fresh water remains high, primarily due to a relatively recent drive towards national "food security" and the consequent very high allocation of water to the thirsty and highly inefficient agricultural sector in that nation. ${ }^{15}$ The use of groundwater has increased markedly in recent years in Syria in an attempt to meet the elevated water demand, and some of the groundwater resources are being heavily over-utilized. ${ }^{16}$ While sources vary considerably in their citations to over-pumped basins in Syria (due to poor data availability, in general), the Aleppo, Bawada/Araj, and Khabour basins all appear to be in this category at present, and the problem is becoming more acute over time as populations grow inexorably.

Third, the allocation of water to the agricultural sector in Israel is also a cause for significant concern. The droughts experienced in 1999-2001 brought this matter into sharp focus, culminating in a highly critical report from a parliamentary committee, which has arguably been a key trigger for a renewed drive for the rapid development of additional desalination facilities in Israel, on a large scale. ${ }^{17}$ The use of water by Israeli settlers in the West Bank is particularly profligate, as was also the case in Gaza prior to so-called "disengagement" in September 2005. ${ }^{18}$ The massive subsidies applied to fresh water provided to the agricultural community in Israel (and to settlers) have served to create great pressure on the use of the regional water resources, ${ }^{19}$ with internal conflicts being evident, in addition to interstate conflict with Palestine and Israel's other neighbors.

Fourth, Jordan faces limited options in relation to its supplies of fresh water, ${ }^{20}$ and the per capita availability of water in Jordan remains very low at present, at about $150 \mathrm{~m}^{3} /$ year. This has generated competition in-country for the water resources, despite considerable efforts to introduce elevated levels of wastewater re-use and to maximize the abstraction rates from aquifers - some of which are fossil resources, such as the Disi Aquifer. ${ }^{21}$ Farmers in the East Ghor (the eastern side of the lower
Jordan river valley) have increasingly resorted to the re-use of wastewaters and to on-site desalination techniques, in attempts to garner sufficient water resources for their needs. ${ }^{22}$ The Red Sea-Dead Sea conduit may also be further considered as a possible source of desalinated water supplies in the future, ${ }^{23}$ although this water would be expensive once it has been pumped to the major demand centers.

And fifth, in Palestine, a crisis exists relating to the so-called Gaza Aquifer (which is in reality merely

a geographical portion of the much larger Coastal Aquifer stretching from northern Israel through Gaza, into north-eastern Egypt). The over-abstraction of water in Gaza (mainly by Palestinians, and due to the high local population and inadequate controls on drilling wells) has led to saline intrusion, and significant contamination by wastewaters exacerbates the situation. ${ }^{24}$ The scenario in the West Bank is also of great concern, with per capita fresh water availability averaging less than $70 \mathrm{~m}^{3} /$ year, and being eroded constantly over time by increases in the population. ${ }^{25}$ Many of the villages in the West Bank possess no piped water supplies, and rely on road tanker deliveries or hand-carried supplies, the latter usually deriving from natural springs. ${ }^{26}$

Under such circumstances, it can hardly be considered surprising that access to fresh water resources constitutes a matter of great concern - and sometimes of societal tension - to many of the communities in the riparians of the Jordan river basin. It has been noted that the imposition of higher prices for water (reflecting the costs of delivery, or scarcity in particular basins) could represent a cause for social unrest in Syria, ${ }^{27}$ and the affordability of water is problematic in all of the Arab riparians to the Jordan river, including Palestine in particular. ${ }^{28}$ Most reports of such difficulties do not reach the national press, far less the international literature. Nevertheless, it is clear that interstate tensions over the allocation of fresh waters are reflected within each of the riparians, with a grumbling discontent among the populations over perceived inequities, coupled to significant problems in relation to the affordability of the resource, even where it is made available. An example of the latter is provided by the very high price of tankered water offered to Palestinians in outlying villages (and also in Gaza), often amounting to orders of magnitude greater than the cost of piped supplies. $^{29}$ 


\section{Costs and economic factors}

Fisher and co-authors have published extensively on the economic costs of water in the Jordan river basin. ${ }^{30}$ This work extended to the use of the so-called WAS (Water Allocation System) model to derive conclusions as to the economic value of water in the region. Estimates were grounded on the replacement costs of water resources, largely on the basis of desalination technology. The studies revealed that the economic value of the regional water resources is far outweighed by the cost of armed hostilities. Thus, for example, the costs of desalination are approximately US $\$ 0.60 / \mathrm{m}^{3}$ using the more recent technologies at a reasonable economy of scale, implying that 1 billion cubic meters of fresh water (almost half of the annual use in Israel as a whole) would cost about US\$600 million to generate. By comparison, the month-long hostilities between Israel and Lebanon in July-August 2006 are estimated to have cost approximately US\$20 billion in total. ${ }^{31}$ The cost of the month-long war between the parties was therefore equivalent to the cost of producing the entire present water supply for Israel by desalination, over a period exceeding thirteen years.

Recently, a positive-sum outcome has been proposed for addressing the problems relating to the water resources of the Jordan river valley. ${ }^{32}$ This avoids the zero-sum scenario where water provided to one riparian is lost by another, in equal volume. The positive-sum outcome relies on the provision of "new water" to the riparians through desalination, wastewater re-use, and possible importation. Estimates of the total volume required by the five riparians prior to 2025 approximate 2-3 billion cubic meters/year, ${ }^{33}$ implying costs of about US $\$ 1.5$ billion annually. Once again, these pale into insignificance by comparison to the costs of even somewhat limited armed hostilities in the region.

It might be argued that the affordability of fresh water supplies from new sources is limited among the riparians, and especially the Arab riparians. Indeed, several authors have stated that there is limited ability among the poorer sectors of the riparian populations to pay for water supplies, and there is a clear need for further attention to pricing policies for water in the region, and also to improved demand management. ${ }^{34}$ The costs of conflict nevertheless outweigh those for supplying additional fresh water by orders of magnitude, and the former costs have been faced by both the riparians and the international community at regular intervals through the last six decades, in many wars since the creation of the state of Israel. It is clear, therefore, that the provision of additional fresh water supplies to the riparians would be cost-effective, if this were to create so-called "spill-over" into cooperation in the broader political arena. ${ }^{35}$ The choice for both the riparians and the international community is clear. Given the previous discussion, it is also evident that improved relationships would extend to the various communities within each of the riparians, and to the various interstate populations - with highly positive geopolitical effects on a global scale.
Notes

David Phillips is the Managing Director of Phillips Robinson and Associates based in Windhoek, Namibia. He can be reached at dphillips@iway.na.

1. For simplicity, the Occupied Palestinian Territories are referred to simply as "Palestine" in the remainder of the article. In cases where the West Bank and Gaza need to be differentiated from each other, they are referred to specifically.

2. See, for example, Lowi (1993); El Musa (1997; 1998); Fredriksen (2003a; 2003b); and Phillips, et al. (2006).

3. For a detailed analysis of the Johnston Plan based on recently declassified documents from U.S. archives, see Phillips, et al. (2007a).

4. See Wolf and Ross (1992); Wolf (1998a, 1998b); and Wolf and Hamner (2000).

5. Phillips, et al. (2006); Jägerskog and Phillips (2006).

6. The attempt to include southern Lebanon within the borders of the eventual Israeli state involved several letters sent in 1920 from Chaim Weizmann, the head of the World Zionist Organization, to various British government officials. See Weisgal (1977); Amery and Kubursi (1992).

7. See note 3 .

8. Naff and Matson (1984).

9. Haddadin (2002); McCaffrey (2003); EURRM (2004).

10. Medzini and Wolf (2004).

11. Selby $(2003,2005)$.

12. Amery and Kubursi (1992); Amery (1993; 2002); ICE (1997).

13. See note 3 .

14. Bakir (2001); Salman (2002); Bazza and Najib (2003); Salman and Mualla (2003a).

15. Phillips, et al. (in preparation) 


\section{See note 14 .}

\section{PCE (2002).}

18. Phillips, et al. $(2004 ; 2005)$.

19. See note 17 .

20. Al-Jayyousi and Shatanawi (1996).

21. Phillips, et al. (2006; 2007b).

22. Fardous and Al-Hadidi (2004).

23. Benvenisti (2004).

24. El-Madhoun (2004, 2005); Abushbak, et al. (2005); Yahya (2005).

25. Phillips, et al. $(2004,2005)$.

26. Data from technical files held by the Palestinian Water Authority, Ramallah, the West Bank.

\section{Varela-Ortega and Sagardoy (2003).}

28. Al-Yaquobi and Hamdan (2005); Scarpa and Abed-Rabbo (2005).

29. Graves (2004).

30. Fisher (1996, 2004); Fisher, et al. (2002).

31. Estimates of the cost of the conflict of July-August 2006 between Israel and Lebanon vary somewhat, according to the source used. Most authorities contend that the cost to Israel was between US\$2 and 5 billion, while the cost to Lebanon was at least US\$15 billion. See Wikipedia (2006) for a range of data sources.

32. Phillips, et al. (2006; 2007b).

33. Phillips, et al. (in preparation).

34. Amery and Kubursi (1992); Salman and Mualla (2003b); Varela-Ortega and Sagardoy (2003); Al-Yaquobi and Hamdan (2005).
35. Phillips, et al. (2006).

\section{References}

Abushbak, T.H., S.M. Medoukh, and R.O. El-Abadla. 2005. "Status of water quality for irrigation in Gaza Strip: Need for national planning and strategy," pp. 112-113 in I. Khatib, K. Assaf, D. Claeys, and A. Al Haj Daoud, eds. Water Values and Rights. Jerusalem: Palestine Academy for Science and Technology.

Al-Jayyousi, O.R. and M.R. Shatanawi. 1996. "An analysis of future water policies in Jordan using decision support systems." International Journal of Water Resources Development, Vol. 11 (3), pp. 315-330.

Al-Yaquobi, A.S. and S.M. Hamdan. 2005. "Constraints facing water resources management in the Gaza Strip," pp. 137-150 in I. Khatib, K. Assaf, D. Claeys, and A. Al Haj Daoud, eds. Water Values and Rights. Jerusalem: Palestine Academy for Science and Technology.

Amery, H.A. 1993. "The Litani River of Lebanon." Geographical Review, Vol. 83 (3), pp. 229-237.

Amery, H.A. 2002. "Irrigation planning in Lebanon: Challenges and opportunities," pp. 111-123 in H.A. Bicak, and O. Mehmet, eds. Water Resource Management: Traditional and Modern Irrigation Technologies in the Eastern Mediterranean. Ottawa: International Development and Research Center.

Amery, H.A. and A.A. Kubursi. 1992. "The Litani River basin: The politics and economics of water." The Beirut Review, Vol 1(3), pp. 95-107. [Beirut: Lebanese Center for Policy Studies.]

Bakir, H. 2001. "Water demand management and pollution control: Key to securing and safeguarding the water supplies of MENA in the 21 st century." Proceedings of the First Regional Conference on Water Demand Management, Conservation and Pollution Control, Amman, Jordan, 7-10 October 2001. Prepared by the WHO Regional Centre for Environmental Health Activities, Amman, Jordan. Available at website http://www.emro.who.int/Publications/CEHA-ESCW A.pdf.

Bazza, M. and R. Najib. 2003. "Towards improved water demand management in agriculture in the Syrian Arab Republic." First National Symposium on Management and Rationalization of Water Resources Use in Agriculture, Damascus, 28-29 April 2003.

Benvenisti, R. 2004. "Addressing the Dead Sea basin water issues." 2nd IsraeliPalestinian International Conference on Water for Life in the Middle East, Antalya, Turkey, 10-14 October 2004. Israel/Palestine Center for Research and Information, Jerusalem.

El-Madhoun, F.I. 2004. "Drinking water quality: Evaluation of chloride and nitrate concentration of well supplies, Gaza Governorates (1990-2002), Palestine." 2nd Israeli-Palestinian International Conference on Water for Life in the Middle East, Antalya, Turkey, 10-14 October 2004. Israel/Palestine Center for Research and 
Information, Jerusalem

El-Madhoun, F.I. 2005. "The status of drinking water quality in Gaza Strip Governorates - Palestine statistical approach,"pp. 220-231 in I. Khatib, K. Assaf, D. Claeys, and A. Al Haj Daoud, eds. Water Values and Rights. Jerusalem: Palestine Academy for Science and Technology.

El-Musa, S. 1997. Water Conflict, Economics, Politics, Law and the PalestinianIsraeli Water Resources. Washington, DC: Institute for Palestine Studies.

E1 Musa, S.S. 1998. "Toward a unified management regime in the Jordan Basin: The Johnston Plan revisited." Yale F\&ES Bulletin, Vol. 103, pp. 297-313.

EURRM. 2004. "EU Rapid Reaction Mechanism - End of Programme Report. Lebanon/ Israel Wazzani Springs Dispute.” Brussels: European Commission Conflict Perevention and Crisis Management Unit.

Fardous, A.-N. and L. Al-Hadidi. 2004. "Wastewater management and reuse in Jordan." 2nd Israeli-Palestinian International Conference on Water for Life in the Middle East, Antalya, Turkey, 10-14 October 2004. Israel/Palestine Center for Research and Information, Jerusalem.

Fisher, F. 1996. "The economics of water dispute resolution, project evaluation and management: An application to the Middle East." International Journal of Water Resources Development, Vol. 11, pp. 377-390.

Fisher, F. 2004. "W ater management, water infrastructure, water negotiations, and water cooperation: The use of the WAS model." 2nd Israeli-Palestinian International Conference on Water for Life in the Middle East, Antalya, Turkey, 10-14 October 2004. Israel/Palestine Center for Research and Information, Jerusalem.

Fisher, F., S. Arlosoroff, Z. Eckstein, M. Haddadin, S.G. Hamati, A. Huber-Lee, A Jarrar, A. Jayyousi, U. Shamir, and H. Wesseling. 2002. "Optimal water management and conflict resolution: The Middle East Water Project." Water Resources Research, Vol. 38 (11), pp. 25(1)-25(13).

Frederiksen, H.D. 2003a. "The world water crisis: Ramifications of politics trumping basic responsibilities of the international community." Water Resources Development, Vol. 19 (4), pp. 593-615.

Frederiksen, H.D. 2003b. "Water: Israeli strategy, implications for peace and the viability of Palestine." Middle East Policy, Vol. X (4), pp. 69-86.

Giordano, M. and A. Wolf. 2003. "Sharing waters: Post-Rio international water management." Natural Resources Forum, Vol. 27, pp. 163-171.

Graves, G. 2004. "From 'emergency response coordination' to 'humanitarian protection': The role and activities of the Emergency W ater and Sanitation-Health (EW ASH) Committee.” 2nd Israeli-Palestinian International Conference on W ater for Life in the Middle East, Antalya, Turkey, 10-14 October 2004. Israel/Palestine Center for Research and Information, Jerusalem.

Haddadin, M.J. 2002. "Rights to the Hasbani?" Daily Star (Lebanon), 18 September 2002
ICE. 1997. "Litani River and Israel-Lebanon." ICE Case Studies, November 1997. Available at www.american.edu/ted/ice/westbank.htm

Jägerskog, A. and D.J.H. Phillips. 2006. "Managing trans-boundary waters for human development." Human Development Report 2006, Occasional Paper 2006/9. Washington, DC: Human Development Report Office, United Nations Development Program

Lowi, M. 1993. Water and Power: The Politics of a Scarce Resource in the Jordan River Basin. Cambridge: Cambridge University Press.

McCaffrey, S. 2003. "W ater disputes defined: Characteristics and trends for resolving them," pp. 49-57 in Resolution of International Water Disputes, Permanent Court of Arbitration, Peace Palace Papers.

Medzini, A. and A.T. Wolf. 2004. "Towards a Middle East at peace: Hidden issues in Arab-Israeli hydropolitics." Water Resources Development, Vol. 20 (2), pp. 193-204

Naff, T. and R.C. Matson. 1984. Water in the Middle East: Conflict or Cooperation Boulder, CO: Westview Press.

PCE. 2002. Parliamentary Committee of Enquiry on the Israeli W ater Sector. Headed by MK David Magan. Report. Jerusalem, June 2002.

Phillips, D.J.H., S. Attili, S. McCaffrey, and J.S. Murray. 2004. "Factors relating to the equitable distribution of water in Israel and Palestine." 2nd Israeli-Palestinian International Conference on Water for Life in the Middle East, Antalya, Turkey, 10-14 October 2004. Israel/Palestine Center for Research and Information, Jerusalem.

Phillips, D.J.H., S. Attili, S. McCaffrey, J.S. Murray, and M. Zeitoun. 2005. "The water rights of the co-riparians to the Jordan River basin," pp. 728-750 in I Khatib, K. Assaf, D. Claeys, and A. Al Haj Daoud, eds. Water Values and Rights. Jerusalem: Palestine Academy for Science and Technology.

Phillips, D.J.H., M. Daoudy, J. Öjendal, A. Turton, and S. McCaffrey. 2006. "Transboundary Water Cooperation as a Tool for Conflict Prevention and for Broader Benefit-sharing." Ministry for Foreign Affairs, Stockholm, Sweden.

Phillips, D.J.H., S. Attili, S. McCaffrey, and J.S. Murray. 2007a. "The Jordan River basin: 1. Clarification of the allocations in the Johnston Plan." Water International, in press.

Phillips, D.J.H., S. Attili, S. McCaffrey, and J.S. Murray. 2007b. "The Jordan River basin: 2. Potential future allocations to the co-riparians." Water International, in press.

Phillips, D.J.H., M. Daoudy, A. Jägerskog, and A. Turton. In preparation. "The Jordan River basin: 3. Options for satisfying the current and future water demand of the five riparians."

Salman, M. 2002. "Case study from Syria - Survey on irrigation modernization. Old Alyarmook project, Alyarmook Basin, southern Syria." Land and Water Development Division, AGLW, Food and Agriculture Organization, Rome. 
Available at http://www.fao.org/landandwater/aglw/watermanagement/docs/ MOD_Syria.stm

Salman, M. and W. Mualla. 2003a. "The utilization of water resources for agriculture in Syria: Analysis of current situation and future challenges." Paper presented at the Erice International Seminars on Planetary Emergencies, 18-26 August 2003, Italy. Available at http://www.wca-infonet.org/servlet/CDSServlet?status= ND0xMjQzLjEwNjcyNyY2PW VuJjMzPWRvY3VtZW 50cyYzNz1pbmZv

Salman, M. and W. Mualla. 2003b. "W ater demand management in Syria: Centralized and decentralized views." Regional Conference on Water Demand Management, Sharm El-Sheikh, Egypt, December 2003. Available at ftp://ftp.fao.org/agl/iptrid/conf_egypt_03.pdf

Scarpa, D.J. and A. Abed-Rabbo. 2005. "Sustainable management of the southern part of the eastern basin of the Mountain Aquifer," pp. 53-66 in I. Khatib, K. Assaf, D. Claeys, and A. A1 Haj Daoud, eds. Water Values and Rights. Jerusalem: Palestine Academy for Science and Technology.

Selby, J. 2003. "Dressing up domination as 'co-operation': the case of IsraeliPalestinian water relations." Review of International Studies, Vol. 29 (1), pp. 121 138.

Selby, J. 2005. "The geopolitics of water in the Middle East: fantasies and realities." Third World Quarterly, Vol. 26 (2), pp. 329-349.

Varela-Ortega, C. and J.A. Sagardoy. 2003. "Irrigation water policies in Syria: Current developments and future options," pp. 277-299 in C. Fiorillo and J. Vercueil, eds. Syrian Agriculture at the Crossroads. Rome: Food and Agriculture Organization.

Weisgal, M.W., ed. 1977. The Letters and Papers of Chaim Weizmann. Jerusalem: Israel University Press.

Wikipedia. 2006. 2006 Lebanon-Israel conflict. Available at http://en.wikipedia.org/wiki/2006_Israel-Lebanon_conflict

Wolf, A.T. 1998a. "Hydrostrategic decision making and the Arab-Israeli conflict." Yale F\&ES Bulletin, Vol. 103, pp. 221-273.

Wolf, A.T. 1998b. "Conflict and cooperation along international waterways." Water Policy, Vol. 1 (2), pp. 251-265.

Wolf, A. and J. Hamner. 2000. "Trends in transboundary water disputes and dispute resolution," pp. 123-148 in M. Lowi and W.D. Shaw, eds. Environment and Security: Discourses and Practices. London: MacMillan.

Wolf, A.T. and J. Ross. 1992. "The impact of scarce water resources on the ArabIsraeli conflict.” Natural Resources Journal, Vol. 32, pp. 919-922.

Yahya, A. 2005. "Gaza project for monitoring groundwater and soil pollution levels in the Gaza Strip," pp. 124-136 in I. Khatib, K. Assaf, D. Claeys, and A. Al Haj Daoud, eds. Water Values and Rights. Jerusalem: Palestine Academy for Science and Technology.

Yoffe, S.B. 2001. "Basins at Risk: Conflict and Cooperation over International
Freshwater Resources.” Ph.D. dissertation, Department of Geosciences, Oregon State University, Oregon.

Yoffe, S. and K. Larson. 2001. "Basins at Risk: Water Event Database Methodology, Chapter 2." Department of Geography, Oregon State University, Corvallis, USA. 